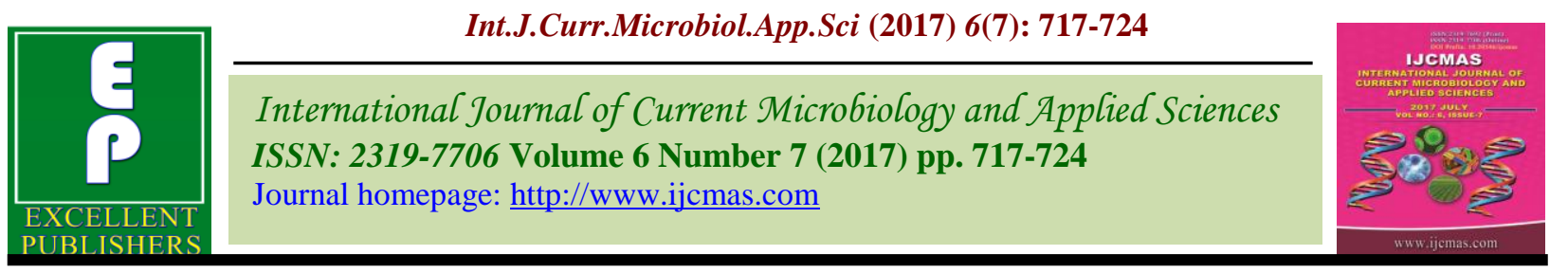

Original Research Article

https://doi.org/10.20546/ijcmas.2017.607.089

\title{
Methods of Irrigation, Fertilizer Approaches and Soil Ameliorant Use in Rabi Sweet Corn (Zea mays saccharata L.) in Lateritic Soils of Konkan
}

\author{
Ashitosh S. Latkar*, U.V. Mahadkar and J.S. Dhekale \\ Department of Agronomy, Dr. B.S. Konkan Krishi Vidyapeeth, Dapoli 415612 (MS) \\ *Corresponding author
}

A B S T R A C T

\begin{abstract}
Keywords
Irrigation, NPK, Micronutrients, Profitability, Soil ameliorant and soil test based approach.

Article Info

Accepted:

14 June 2017

Available Online:

10 July 2017
\end{abstract}

Two years field experiment was conducted during consecutive years of rabi 2012-13 to 2013-14 at Department of Agronomy, Dr. BSKKV, Dapoli on lateritic soils of Konkan, to determine suitability of irrigation method, fertilizer approaches and levels of soil ameliorant to sweet corn. Sweet corn grown under drip irrigation noticed significantly higher green cob, fodder and total biomass (1.67, 1.73 and $3.40 \mathrm{t} / \mathrm{ha}$, respectively) with increment of $10.78,4.05$ and $7.35 \%$, respectively over check basin method of irrigation. Application of soil test based fertilizer requirement of $\mathrm{N}, \mathrm{P}, \mathrm{K}$ and micronutrients $(\mathrm{Cu}, \mathrm{Zn}$, $\mathrm{B}$ and $\mathrm{Mn}$ ) had significantly highest green cob yield (2.05 t/ha) and increment was 71.66 , 13.27 and $5.97 \%$ over control, recommended dose of fertilizer and soil test based fertilizer requirement of NPK, respectively. However, corn ameliorated with $50 \%$ lime requirement recorded the highest green cob and fodder yield (1.67 and $1.74 \mathrm{t} / \mathrm{ha}$, respectively) with increment in the magnitude of $10.40 \%$ and $6.03 \%$, respectively over lime control and $25 \%$ lime requirement. Economics of treatments revealed that, drip irrigated sweet corn has more net monetary returns (₹ $151.17 \times 10^{3} / \mathrm{ha}$ ) with benefit: cost ratio of $2.16: 1$. Sweet corn grown with application of soil test based fertilizer requirement of $\mathrm{N}, \mathrm{P}, \mathrm{K}$ and micronutrients $(\mathrm{Cu}, \mathrm{Zn}, \mathrm{B}$ and $\mathrm{Mn})$ noticed profitable yield potential with high net returns of ₹ $257.14 \times 10^{3} /$ ha and 2.31:1 benefit: cost ratio. However, corn ameliorated with $50 \%$ lime requirement recorded highest net returns $₹ 210.84 \times 10^{3} /$ ha, but profitability was highest with application of $25 \%$ lime requirement with $\mathrm{B}: \mathrm{C}$ ratio of $2.20: 1$.

\section{Introduction}

The corn is also called the Indian corn, sweet corn, sugar corn or pole corn. Sweet corn is peculiarly an American crop and introduced in India from USA. Sweet corn (Zea mays saccharata L.) is one of the groups of maize (Zea mays) and is classified on the basis of kernel characteristics which have high sugar content in the milk on early dough stage. The higher content of water soluble polysaccharide in the kernel adds texture and quality in addition to sweetness (Venkatesh $e t$ al., 2003).
Sweet corn is a versatile crop, which finds place in the human diet, animal food, fodder and industrial raw material. It is bred to have a higher level of natural sugars, which makes it very popular in rural as well as in urban area.

The red lateritic soil of konkan region is characterized by distinct acidity by presence of $\mathrm{Al}, \mathrm{Fe}$ and $\mathrm{Mn}$ in soil solution at toxic level as majority of bases are removed by intense rainfall. Nutritional imbalance due to increase 
or decrease concentration of ions in the soil solution, deficiency of phosphorus, boron, zinc and molybdenum and poor microbiological activity leading to low availability of nitrogen and sulphur. Since, application of lime to acid soil can stimulate crop growth by eliminating toxicities of $\mathrm{Al}$ and $\mathrm{Mn}$ and increase the availability of certain plant nutrients (Fageria and Baligar, 2008).

The luxurious corn production under application of major and micro nutrients based on soil test approach is necessary to get full advantage of applied nutrients with higher nutrient use efficiency of nutrients. Though annual rainfall is exceeding $>3000 \mathrm{~mm}$, the cool temperature and water shortage in post rainy season is very common in konkan region. To cope up such condition and better water use efficiency during rabi season through water saving and by use of micro irrigation techniques has key role not only in increased profit by raising crop yield by 20 to 100 per cent as compared to conventional method but also saving of labour.

Beware of this sweet corn can be a promising and high yield potential, short duration cash crop with wide scope for cultivation during rabi season. Proper managerial practices fetches better market price under konkan region. Therefore, there is need to ameliorate the soil by using desired quantity of liming materials like $\mathrm{CaCO}_{3}$, suitable fertilizer approach and to mitigate water requirement in post rainy season with high water use efficiency. Hence, effort was undertaken to study use of soil ameliorant, soil test based fertilizer approach for macro and micronutrients and irrigation methods which can envisage not only the productivity of crop but also sustaining soil health.

\section{Materials and Methods}

Field experiment was conducted at Agronomy farm, Department of Agronomy, Dr.
B.S.K.K.V., Dapoli during two consecutive rabi seasons of 2012-13 and 2013-14. The plot representing acidic $\mathrm{pH}$ (5.63) was selected for experimentation which was moderately high in organic carbon content (0.98\%), medium in available nitrogen (371.14 kg/ha), low in available phosphorus $(10.86 \mathrm{~kg} / \mathrm{ha})$ and fairly high in available potassium $(265.90 \mathrm{~kg} / \mathrm{ha})$.

Experimental plot has high in available copper $(1.92 \mathrm{mg} / \mathrm{kg})$ and manganese $(60.52$ $\mathrm{mg} / \mathrm{kg})$, while low in zinc $(0.42 \mathrm{mg} / \mathrm{kg})$ and boron $(0.27 \mathrm{mg} / \mathrm{kg})$ content.

Main plot (horizontal levels) treatments consisting two irrigation methods viz., check basin and drip irrigation and vertical levels consisted four different fertilizer applications approaches viz. control, recommended dose of fertilizer (200:60:60 NPK kg/ha), soil test based fertilizer requirement of NPK (200:75:60 NPK kg/ha) and soil test based fertilizer requirement of NPK and micronutrients $(\mathrm{Cu}, \mathrm{Zn}, \mathrm{B}$ and $\mathrm{Mn})$ i.e. 200:75:60 NPK kg/ha and copper $3 \mathrm{~kg} / \mathrm{ha}$, zinc $6.25 \mathrm{~kg} / \mathrm{ha}$ and boron $1.25 \mathrm{~kg} / \mathrm{ha}$. Sub plot treatment comprised of 3 levels of soil ameliorant as, lime control, 25\% lime requirement and $50 \%$ lime requirement to ameliorate the soil. Lime requirement was determined as procedure given by Shoemaker et al., (1961).

Analysis was done using strip split plot design with three replications. Sweet corn cultivar Sugar-75 was sown in paired row planting system with $60 \times 30-30 \mathrm{~cm}$ spacing. The fertilizers were applied as per treatments. The full dose of $\mathrm{P}, \mathrm{K}$ and all micronutrients were applied as basal dose, while nitrogen was applied in three splits i.e. $50 \% \mathrm{~N}$ at time of sowing and remaining $\mathrm{N}$ was top dressed in 2 equal splits (at $30 \mathrm{DAS}$ and at $60 \mathrm{DAS}$ ). The periodic growth observations were recorded at 15 days interval. 


\section{Results and Discussion}

\section{Yield attributes and yield}

Green cob, green fodder and total biomass yield of sweet corn was significantly influenced and recorded highest under drip method of irrigation over check basin irrigation. The increment in green cob, green fodder and total biomass yield was to the magnitude of $10.43,4.17$ and $7.25 \%$, respectively over check basin method of irrigation (Table 1). The drip irrigated corn also recorded significantly higher number of cobs per ha during both years of experimentation. This may be ascribed due maintenance of ample soil rhizosphere moisture throughout the crop growing season owed to drip irrigation method and this is congenial for growth and development of higher yield attributes and subsequently into crop yields. Gautam et al., (2000) reported under moisture stress condition all the growth factors were affected adversely to a greater extent in check basin irrigation. These findings are in line with the findings of Bharati et al., (2007) and Ramulu et al., (2010).

Sweet corn applied with soil test based fertilizer requirement of NPK and micronutrients $(\mathrm{Cu}, \mathrm{Zn}, \mathrm{B}$ and $\mathrm{Mn})$ recorded significantly the highest green cob, green fodder and total biomass yield 2.05, 2.0 and $4.05 \mathrm{t} / \mathrm{ha}$, respectively with increment to the tune of $5.97,13.27$ and $71.66 \%$, respectively over soil over test based fertilizer requirement of NPK, recommended dose of fertilizer and control in that descending order of significance.

Moreover, green cob yield recorded with treatment soil test based fertilizer requirement of NPK and recommended dose of fertilizer were at par with each other. The number of cobs per ha was also significantly higher in soil test based fertilizer requirement of NPK and micronutrients $(\mathrm{Cu}, \mathrm{Zn}, \mathrm{B}$ and $\mathrm{Mn})$ over control during both years. The results are in agreement with those reported by Paramasivan et al., (2011). Optimum availability of major as well as micro nutrient often may lead higher growth and yield attributes which might be reflected significantly in higher green cob and fodder yield of corn compared to rest of fertilizer approaches. These results were attributed by Gzazia et al., (2003) and Bindhani et al., (2007).

The elevated levels of application of lime requirement has significant effect on green $\mathrm{cob}$, green fodder, total biomass and number of cobs per ha. Soil ameliorated with 50\% lime requirement recorded significantly more green cob (1.67 t/ha) and fodder yield (1.74 t/ha) of sweet corn over soil ameliorated with $25 \%$ lime requirement $(1.57 \mathrm{t} / \mathrm{ha})$ and lime control (1.50 t/ha). Increase in green cob yield over lime control and 25\% lime requirement due to $50 \%$ soil amelioration was to the tune of 10.40 and 4.64 per cent, respectively. Amelioration of soil owing to lime application might have reduced the soil acidity, improved base saturation $\mathrm{pH}$, reduced toxicity of elements $\mathrm{Al}, \mathrm{Fe}$ and $\mathrm{Mn}$ as corroborated by Dixit and Sharma (1993). Similarly, Dixit (2006) reported, the phosphorus level in soil was increased due to elevated levels of soil ameliorants and as phosphorus is an essential nutrient being involved in strengthening of roots, cell division, elongation, production of ATP and various metabolic reactions, thereby improving the productivity of crops which might have improved the crop yield.

\section{Economics}

Drip irrigated sweet corn recorded higher net returns (₹ $218.15 \times 10^{3} / \mathrm{ha}$ ) with more benefit: cost ratio of $2.16: 1$ over check basin method of irrigation method (₹151.17 $\times 10^{3} / \mathrm{ha}$ and 1.95:1 B: C ratio). 
Table.1 Effect of irrigation methods, fertilizer approaches and soil ameliorant on green cob, fodder and total biomass yield of sweet corn (two years pooled mean)

\begin{tabular}{|c|c|c|c|c|c|}
\hline \multirow[t]{2}{*}{ Treatments } & \multirow{2}{*}{$\begin{array}{l}\text { Green cob } \\
\text { yield (t/ha) }\end{array}$} & \multirow{2}{*}{$\begin{array}{l}\text { Green fodder } \\
\text { yield (t/ha) }\end{array}$} & \multirow{2}{*}{$\begin{array}{l}\text { Total } \\
\text { Biomass } \\
\text { (t/ha) } \\
\end{array}$} & \multicolumn{2}{|c|}{$\begin{array}{l}\text { Number of } \\
\text { cobs/ha }\end{array}$} \\
\hline & & & & 2012-13 & 2013-14 \\
\hline \multicolumn{6}{|l|}{ Irrigation methods (I) } \\
\hline Check basin & 1.49 & 1.66 & 3.15 & 63457 & 65500 \\
\hline Drip irrigation & 1.67 & 1.73 & 3.40 & 72237 & 75013 \\
\hline S.Em. \pm & 0.01 & 0.01 & 0.02 & 2831 & 2400 \\
\hline C.D. at $5 \%$ & 0.04 & 0.04 & 0.07 & 8589 & 7230 \\
\hline \multicolumn{6}{|l|}{ Fertilizer approaches $(\mathbf{F})$} \\
\hline Control & 0.58 & 1.00 & 1.58 & 59743 & 61249 \\
\hline RDF (200:60:60 NPK Kg ha-1) & 1.78 & 1.88 & 3.65 & 68247 & 70949 \\
\hline Soil test based fertilizer requirement of NPK & 1.92 & 1.90 & 3.83 & 70102 & 71506 \\
\hline $\begin{array}{l}\text { Soil test based fertilizer requirement of NPK and Micronutrients } \\
(\mathrm{Cu}, \mathrm{Zn}, \mathrm{B} \text { and } \mathrm{Mn})\end{array}$ & 2.05 & 2.00 & 4.05 & 73296 & 77323 \\
\hline S.Em. \pm & 0.01 & 0.01 & 0.01 & 559 & 580 \\
\hline C.D. at $5 \%$ & 0.02 & 0.03 & 0.04 & 1685 & 1741 \\
\hline \multicolumn{6}{|l|}{ Soil ameliorant (L) } \\
\hline Control & 1.50 & 1.63 & 3.13 & 61991 & 63989 \\
\hline $25 \%$ Lime requirement & 1.57 & 1.71 & 3.28 & 69735 & 72629 \\
\hline $50 \%$ Lime requirement & 1.67 & 1.74 & 3.42 & 71815 & 74152 \\
\hline S.Em. \pm & 0.00 & 0.00 & 0.01 & 447 & 422 \\
\hline C.D. at $5 \%$ & 0.01 & 0.01 & 0.02 & 1345 & 1267 \\
\hline \multicolumn{6}{|l|}{ Interactions } \\
\hline IX F & $\mathrm{NS}$ & NS & NS & SIG & SIG \\
\hline IX L & NS & SIG & NS & SIG & SIG \\
\hline F X L & SIG & SIG & SIG & NS & NS \\
\hline I XF X L & NS & NS & NS & NS & NS \\
\hline General mean & 1.58 & 1.69 & 3.27 & 67847 & 70257 \\
\hline
\end{tabular}


Table.2 Interaction effects between fertilizer approaches X levels of soil ameliorant on green cob, fodder and total biomass yield ( $\mathrm{t} / \mathrm{ha}$ ) of sweet corn

\begin{tabular}{|c|c|c|c|c|c|c|c|c|c|}
\hline \multirow{2}{*}{ Treatments } & \multicolumn{3}{|c|}{ Green cob yield (t/ha) } & \multicolumn{3}{|c|}{ Green fodder yield (t/ha) } & \multicolumn{3}{|c|}{ Total biomass yield (t/ha) } \\
\hline & $\mathbf{L}_{\mathbf{0}}$ & $\mathbf{L}_{1}$ & $\mathbf{L}_{2}$ & $\mathbf{L}_{\mathbf{0}}$ & $\mathbf{L}_{1}$ & $\mathbf{L}_{2}$ & $\mathbf{L}_{\mathbf{0}}$ & $\mathbf{L}_{1}$ & $\mathbf{L}_{2}$ \\
\hline $\mathbf{F}_{\mathbf{0}}$ & 0.45 & 0.58 & 0.71 & 0.89 & 1.01 & 1.08 & 1.35 & 1.59 & 1.79 \\
\hline $\mathbf{F}_{1}$ & 1.67 & 1.78 & 1.87 & 1.79 & 1.90 & 1.88 & 3.52 & 3.68 & 3.75 \\
\hline $\mathbf{F}_{2}$ & 1.92 & 1.95 & 1.91 & 1.85 & 1.94 & 1.96 & 3.71 & 3.89 & 3.87 \\
\hline $\mathbf{F}_{3}$ & 1.96 & 1.98 & 2.20 & 1.97 & 1.98 & 2.04 & 3.94 & 3.95 & 4.25 \\
\hline S.Em. \pm & \multicolumn{3}{|l|}{0.02} & \multicolumn{3}{|l|}{0.01} & \multicolumn{3}{|l|}{0.03} \\
\hline C.D. at $5 \%$ & \multicolumn{3}{|l|}{0.05} & \multicolumn{3}{|l|}{0.04} & \multicolumn{3}{|l|}{0.09} \\
\hline
\end{tabular}

Table.3 Interaction effects between irrigation methods X levels of soil ameliorant on green fodder yield (t/ha) of sweet corn

\begin{tabular}{|l|l|l|l|}
\hline \multirow{2}{*}{ Treatments } & \multicolumn{3}{|l|}{ Green fodder yield (t/ha) } \\
\cline { 2 - 4 } & $\mathbf{L}_{\mathbf{0}}$ & $\mathbf{L}_{\mathbf{1}}$ & $\mathbf{L}_{\mathbf{2}}$ \\
\hline $\mathbf{I}_{\mathbf{1}}$ & 161.46 & 167.45 & 168.10 \\
\hline $\mathbf{I}_{\mathbf{2}}$ & 164.35 & 174.06 & 180.24 \\
\hline S.Em. \pm & 0.62 & & \\
\hline C.D. at 5\% & 1.89 & \multicolumn{2}{|l}{} \\
\hline
\end{tabular}

Table.4 Interaction effects between irrigation methods X levels of soil ameliorant on number of cobs/ha of sweet corn

\begin{tabular}{|l|l|l|l|l|l|l|}
\hline \multirow{2}{*}{ Treatments } & $\mathbf{2 0 1 2 - 1 3}$ & $\mathbf{2 0 1 3 - 1 4}$ & $\mathbf{L}_{\mathbf{1}}$ & $\mathbf{L}_{\mathbf{2}}$ \\
\cline { 2 - 8 } & $\mathbf{L}_{\mathbf{0}}$ & $\mathbf{L}_{\mathbf{1}}$ & $\mathbf{L}_{\mathbf{2}}$ & $\mathbf{L}_{\mathbf{0}}$ & 66298 & 66364 \\
\hline $\mathbf{I}_{\mathbf{1}}$ & 61713 & 64144 & 63958 & 63840 & 78960 & 81941 \\
\hline $\mathbf{I}_{\mathbf{2}}$ & 62268 & 75325 & 79673 & 64138 & 848 & \\
\hline S.Em. \pm & 899 & & 2534 & & \\
\hline C.D. at 5\% & 2690 & & & & \\
\hline
\end{tabular}


Table.5 Interaction effects between fertilizer approaches X irrigation methods on number of cobs/ha of sweet corn.

\begin{tabular}{|l|l|l|l|l|}
\hline \multirow{2}{*}{ Treatments } & \multicolumn{2}{|l|}{$\mathbf{2 0 1 2 - 1 3}$} & $\mathbf{2 0 1 3 - 1 4}$ \\
\cline { 2 - 5 } & $\mathbf{I}_{\mathbf{1}}$ & $\mathbf{I}_{\mathbf{2}}$ & $\mathbf{I}_{\mathbf{1}}$ & $\mathbf{I}_{\mathbf{2}}$ \\
\hline $\mathbf{F}_{\mathbf{0}}$ & 54552 & 64933 & 56312 & 66186 \\
\hline $\mathbf{F}_{\mathbf{1}}$ & 61186 & 67089 & 64696 & 70773 \\
\hline $\mathbf{F}_{\mathbf{2}}$ & 68683 & 71520 & 69869 & 73144 \\
\hline $\mathbf{F}_{\mathbf{3}}$ & 69405 & 85405 & 71125 & 89950 \\
\hline S.Em. \pm & 1148 & & 1009 & \\
\hline C.D. at 5\% & 3449 & 3028 & \\
\hline
\end{tabular}

Table.6 Effect of irrigation methods, fertilizer approaches and soil ameliorant on economics of sweet corn

\begin{tabular}{|c|c|c|c|c|}
\hline Treatments & $\begin{array}{l}\text { Cost of Cultivation } \\
\left(\mathrm{X} ₹ 10^{3} / \mathrm{ha}\right)\end{array}$ & $\begin{array}{l}\text { Gross Returns } \\
\left(\mathrm{X} ₹ 10^{3} / \mathrm{ha}\right)\end{array}$ & $\begin{array}{l}\text { Net Returns } \\
\left(\mathrm{X} ₹ \mathbf{1 0}^{\mathbf{3}} / \mathrm{ha}\right)\end{array}$ & $\mathrm{B}: \mathrm{C}$ ratio \\
\hline \multicolumn{5}{|l|}{ Irrigation methods (I) } \\
\hline Check basin & 159.16 & 310.33 & 151.17 & 1.95 \\
\hline Drip irrigation & 188.39 & 406.55 & 218.15 & 2.16 \\
\hline \multicolumn{5}{|l|}{ Fertilizer approaches $(\mathbf{F})$} \\
\hline Control & 139.04 & 215.72 & 76.67 & 1.55 \\
\hline RDF (200:60:60 NPK kg ha ${ }^{-1}$ ) & 176.14 & 367.29 & 191.16 & 2.09 \\
\hline Soil test based fertilizer requirement of NPK & 183.11 & 396.80 & 213.69 & 2.17 \\
\hline $\begin{array}{l}\text { Soil test based fertilizer requirement of NPK and } \\
\text { Micronutrients }(\mathrm{Cu}, \mathrm{Zn}, \mathrm{B} \text { and } \mathrm{Mn})\end{array}$ & 196.82 & 453.96 & 257.14 & 2.31 \\
\hline \multicolumn{5}{|l|}{ Soil ameliorant $(\mathbf{L})$} \\
\hline Control & 149.43 & 286.39 & 136.96 & 1.92 \\
\hline $25 \%$ Lime requirement & 171.83 & 378.02 & 206.19 & 2.2 \\
\hline $50 \%$ Lime requirement & 200.07 & 410.90 & 210.84 & 2.05 \\
\hline General mean & 173.78 & 358.44 & 184.66 & -- \\
\hline
\end{tabular}


Soil test based fertilizer requirement of NPK and micronutrients $(\mathrm{Cu}, \mathrm{Zn}, \mathrm{B}$ and $\mathrm{Mn})$ recorded the highest net returns with higher benefit to cost ratio $\left(257.14 \times 10^{3} / \mathrm{ha}\right.$ and 2.17:1 over soil test based fertilizer requirement of NPK, recommended dose of fertilizer approach and control. Those results are confirmatory with those reported by Viswanatha et al., (2000). Though, there were meager differences among $50 \%$ lime requirement and $25 \%$ lime requirement in respect of gross and net monitory returns of sweet corn due to levels of soil ameliorant. The soil ameliorated with 50\% lime requirement showed higher net monitory return of corn $\left(210.84 \times 10^{3} /\right.$ ha) over the corn gown on soil ameliorated with $25 \%$ lime requirement $\left(206.19 \times 10^{3} / \mathrm{ha}\right)$ and lime control $\left(136.96 \times 10^{3} / \mathrm{ha}\right)$. However, the profitability in terms of benefit: cost ratios was found to be maximum with corn ameliorated with $25 \%$ lime requirement was 2.20:1 with sustained yield (Table 6).

\section{Interaction effects}

The green cob, green fodder and total biomass yield of sweet corn was significantly influenced by interaction between different fertilizer approaches and levels of soil ameliorants. The nutrients applied as per soil test based fertilizer requirement of NPK and micronutrients $(\mathrm{Cu}, \mathrm{Zn}, \mathrm{B}$ and $\mathrm{Mn})$ approach and soil ameliorated with $50 \%$ lime requirement produced significantly highest green cob, green fodder and total biomass yield (2.20, 2.04 and $4.25 \mathrm{t} / \mathrm{ha}$, respectively) of sweet corn over rest of treatment combinations (Table 2). These results are in conformity with the results reported by Selvaraju and Iruthayaraj (1995) and Kamala kumari and Singaram (1996).

The interaction effect between irrigation methods and levels of soil ameliorants was significant for green fodder yield of corn, and sweet corn grown under drip irrigation method on soil ameliorated with 50\% lime required recorded highest green fodder yield $(180.24 \mathrm{t} / \mathrm{ha})$ over rest of treatment combinations (Table 3).

The interaction for number of cobs per ha was also found significant. The sweet corn grown under drip irrigation method on soil ameliorated with $50 \%$ lime required noticed highest number of cobs per ha (79673 and 81941) during rabi 2011-12 and rabi 201213, respectively over other treatment combinations (Table 4). Whereas, drip irrigated corn supplied with nutrients as per soil test based fertilizer requirement of NPK and micronutrients ( $\mathrm{Cu}, \mathrm{Zn}, \mathrm{B}$ and $\mathrm{Mn}$ ) approach registered significantly highest number of cobs per ha i.e. 85405 and 89950 during rabi 2011-12 and rabi 2012-13, respectively (Table 5).

In conclusion, under konkan condition sustainable yield production and profitability of sweet corn during rabi season could be achieved by raising sweet corn under drip irrigation on the soil, ameliorated with $25 \%$ lime requirement with soil test based fertilizer requirement of NPK and micronutrient $(\mathrm{Cu}$, $\mathrm{Zn}, \mathrm{B}$ and $\mathrm{Mn}$ ).

\section{References}

Bharati, V., Nandan Ravi, Vinod Kumar and Pandey, I.B. 2007. Effect of irrigation levels on yield, water use efficiency and economics of winter maize (Zea mays)based intercropping system. Indian J. Agron., 52(1): 27-30.

Bindhani, A., Barik, K.C., Garnayak, L.M. and Mahapatra, P.K. 2007. Nitrogen management in baby corn (Zea mays.), Indian J. Agron., 52(2): 135-38.

Dixit S.P. 2006. Effect of lime and phosphorus on yield and nutrient uptake by maize in mountain acidic soil of 
Himachal Pradesh. Annals of Agri. Res., New Series 27(3): 277-82.

Dixit, S.P. and Sharma, P.K. 1993. Effect of lime and potassium on yield and uptake of nutrients in wheat (Triticum aestivum), soybean (Glycine max) and linseed (Linum usitatissimum) cropping sequence in an acid alfisol. Indian $J$. Agri. Sci., 63(6): 339-49.

Fageria, N.K. and Baligar, V.C. 2008. Ameliorating soil acidity of tropical Oxisols by liming for sustainable crop production. Adv. Agron., 99: 345-99.

Gautam, R.C., Pachuri, P., Singh V. and Gaur, N. S. 2000. Response of winter maize (Zea mays) to irrigation schedule and tassel removal. Indian J. Agri. Sci., 70(12): 859-60.

Gzazia, J.D., Tittonell, P.A., Germinara, D. and Chiesa, A. 2003. Phosphorus and nitrogen fertilization in sweet corn (Zea mays saccharata). Spanish J. Agri. Res., 1(2): 103-07.

Kamala kumara, K. and Singaram, P. 1996. Quality parameters of maize as influenced by application of fertilizers and manures. Madras Agri. J., 83(1): 32-33.

Paramasivan, M., Kumaresan, K.R., Malvaravizhi, P., Mahimairaja, S. and Velayudham, K. 2011. Effect of different levels of NPK and Zn on yield and nutrient uptake of Hybrid maize (COHM 5) in Pilamedu and Palaviduthi series of Tamil Nadu. Madras Agri. J., 98(10-12): 334-38.

Ramulu, V., Reddy M.D. and Rao, A.M. 2010. Response of rabi maize to irrigation schedules and fertigation levels. Agri. Sci. Digest, 30(2): 104-06.

Selvaraju, R. and Iruthayaraj, M.R. 1995. Effect of irrigation, methods of irrigation and nitrogen levels on nutrient uptake by maize (Zea mays). Madras Agri. J., 82(3): 215-16.

Shoemaker, H.E., McLean E.O. and Pratt, P.F. 1961. Buffer methods for determining lime requirement of soils with appreciable amounts of extractable aluminum. Proceeding Soil Science Society of America, 25(4): 274-77.

Venkatesh, S., Rakshit Ajay and Sekhar, J.C. 2003. Sweet corn. Speciality corn Technical Series 1, Directorate of Maize research, New Delhi. pp. 1-3.

Viswanatha, G.B., Ramchandrappa, B.K. and H.V. Nanjappa. 2000. Effect of drip irrigation and methods of planting on Root and Shoot biomass, Tasseling Silking interval, Yield and Economics of sweet corn (Zea mays L. Cv. Saccharata). Mysore J. Agri. Sci., 34: 134-41.

\section{How to cite this article:}

Ashitosh S. Latkar, U.V. Mahadkar and Dhekale, J.S. 2017. Methods of Irrigation, Fertilizer Approaches and Soil Ameliorant Use in Rabi Sweet Corn (Zea mays saccharata L.) in Lateritic Soils of Konkan. Int.J.Curr.Microbiol.App.Sci. 6(7): 717-724. doi: https://doi.org/10.20546/ijcmas.2017.607.089 